\title{
NORM INEQUALITIES FOR THE CHAOTICALLY GEOMETRIC MEAN AND ITS REVERSE
}

\author{
YUKI SEO
}

Abstract. Let $A$ and $B$ be strictly positive operators on a Hilbert space $H$ such that $0<m \leqslant$ $B \leqslant M$ for some scalars $0<m<M$ and $h_{B}=\frac{M}{m}$. We prove a norm inequality for the chaotically geometric mean $A \diamond \alpha B=e^{(1-\alpha) \log A+\alpha \log B}$ and its reverse: For each real number $\alpha \in \mathbb{R}$

$$
S\left(h_{B}^{\alpha}\right)^{-1}\left\|A^{\frac{1-\alpha}{2}} B^{\alpha} A^{\frac{1-\alpha}{2}}\right\| \leqslant\|A \diamond \alpha B\| \leqslant\left\|A^{\frac{1-\alpha}{2}} B^{\alpha} A^{\frac{1-\alpha}{2}}\right\|
$$

where the constant $S(h)$ is the Specht ratio and $\|\cdot\|$ is the operator norm.

Mathematics subject classification (2000): 47A63.

Key words and phrases: Positive operator, Araki's inequality, chaotically geometric mean, Specht ratio, a generalized Kantorovich constant, reverse inequality.

\section{REFERENCES}

[1] H. ARAKI, On an inequality of Lieb and Thirring, Letters in Math. Phys., 19 (1990), 167-170.

[2] R. Bhatia, Matrix Analysis, Springer, Germany, 1996.

[3] J.C. Bourin AND Y. SEO, Reverse inequality to Golden-Thompson type inequalities: Comparison of $e^{A+B}$ and $e^{A} e^{B}$, preprint.

[4] J.I. FuJII, M. FujII, Y. SeO And M. Tominaga, On generalized Kantorovich inequalities, Proc. Int. Sym. on Banach and Function Spaces, Kitakyushu, Japan, October 2-4, (2003), 205-213.

[5] J.I. FUJII, Y. SEO AND M. TOMINAGA, Kantorovich type operator inequalities via the Specht ratio, Linear Alg. Appl., 377(2004), 69-81.

[6] M. FuJII AND R. NAKAMOTO, A geometric mean in the Furuta inequality, Sci. Math. Japon., 55 (2002), $615-621$.

[7] M. FuJII AND Y. SEO, Reverse inequalities of Araki, Cordes and Löwner-Heinz inequalities, Nihonkai Math. J., 16 (2005), 145-154.

[8] T. FuRUTA, Specht ratio $S(1)$ can be expressed by Kantorovich constant $K(p): S(1)=\exp K^{\prime}(1)$ and its application, Math. Inequal. Appl., 6 (2003), 521-530.

[9] T. Furuta, J. Mićić, J.E. PeČARIĆ And Y. SeO, Mond-Pečarić Method in Operator Inequalities, Monographs in Inequalities 1, Element, Zagreb, 2005.

[10] R. NAKAMOTO AND Y. SEO, Norm inequalities for the geometric mean and its reverse, Sci. Math. Japon., 65, No. 2(2007), 281-286, :e2006, 1209-1214.

[11] R. NAKAMOTO AND Y. SEO, A complement of the Ando-Hiai inequality and norm inequalities for the geometric mean, preprint.

[12] W. SPECHT, Zur Theorie der elementaren Mittel, Math. Z., 74(1960), 91-98.

[13] A.M. TURING, Rounding off-errors in matrix processes, Quart. J. Mech. Appl. Math., 1(1948), 287-308.

[14] T. YAMAZAKI AND M. YANAGIDA, Characterizations of chaotic order associated with Kantorovich inequality, Sci. Math., 2(1999), 37-50. 